\title{
On the Subzero Temperature Preservation of Fertilized Eggs of Rainbow Trout
}

\author{
Yukio HAGA* \\ (Received May 4, 1982)
}

\begin{abstract}
A possibility of preservation of fertilized eggs of rainbow trout Salmo gairdneri was examined at $-7^{\circ} \mathrm{C} \sim-20^{\circ} \mathrm{C}$ for 3 hours. The results obtained are summarized as follows;

1. Eggs after eyed stage had higher tolerance for subzero temperature exposure than those of before eyed stage. $2.1 \mathrm{M}$.

2. Suitable concentration of dimethyl sulfoxide (DMSO) as organic cryoprotectant was $1.4 \sim$

3. In $-7^{\circ} \mathrm{C}$ exposure, about $95 \%$ of hatching rate was obtained by using $10 \%$ calf serum and mineral salts solution besides DMSO as cryoprotectants, while $14 \%$ of hatching rate was obtained in $-12^{\circ} \mathrm{C}$ exposure.
\end{abstract}

The cryopreservation of fish sperm has been investigated by many authors. ${ }^{1-10}$ Scientific reports on the subzero temperature preservation of fish eggs are, however, comparatively few. WHITINGHAM \& ROSENTHAL ${ }^{11)}$ reported about subzero temperature preservation of fertilized eggs of Atlantic herring. But there is no report concerning the subzero temperature preservation of fertilized eggs of freshwater fish.

This report deals with a possibility of subzero temperature preservation of fertilized eggs of rainbow trout as a model of cryopreservation of fertilized eggs of valuable cultured freshwater fish.

\section{Materials and Methods}

Eggs used were hand-stripped from the matured female rainbow trout obtained from fish culturist. The eggs were artificially fertilized by isotonic method after rinsing eggs with physiological saline. ${ }^{12)}$ They were incubated at $c a .12^{\circ} \mathrm{C}$ in Atkins style incubators until used in the experiments. And temperature units were found from the daily mean value of water temperature.

Through the experiments, eggs tested were placed in several aquatic media consist of mineral salts and organic cryoprotectants. The mineral salts solution was composed of $3.2 \mathrm{mM} \mathrm{KCl}, 2.3$ $\mathrm{mM} \mathrm{CaCl} \cdot 2 \mathrm{H}_{2} \mathrm{O}$ and 154,171 and $188 \mathrm{~mm} \mathrm{NaCl}$. DMSO, glucose and calf serum were added to mineral salts solutions as cryoprotectants.
Thirty fertilized eggs were placed in a test tube (22 $\mathrm{mm}$ in diameter) having $20 \mathrm{ml}$ of a medium previously cooled to $4.0 \sim 7.2^{\circ} \mathrm{C}$. Then, the test tube containing eggs and medium was placed in a cooling bath and cooled at the rate of $0.4^{\circ} \sim 0.9^{\circ} \mathrm{Cl}$ $\min$ until $-5^{\circ} \mathrm{C}$ and at $0.7^{\circ} \sim 8.9^{\circ} \mathrm{C} / \mathrm{h}$ below $-5^{\circ} \mathrm{C}$. After the test tubes were exposed to the constant subzero temperature for 3 hours, they were taken out from the cooling bath and kept in a water tank filled with $\mathrm{ca} .12^{\circ} \mathrm{C}$ water for rising the eggs' temperature. The eggs warmed to $12^{\circ} \mathrm{C}$ were placed on incubator trays, and washed several times by water, then they were replaced into the incubator to observe whether or not hatching had occurred. Hatching rates were shown as the indices comparing with the hatching numbers of untreated eggs.

Eggs were carefully handled with tweezers made of feathers of water bird. The temperature was monitored by a thermojunction thermometer.

\section{Results and Discussion}

\section{Developmental Stage and Subzero Temperature Tolerance}

Five different stages of eggs were examined to investigate the suitable stage regarding subzero temperature tolerance. As shown in Table 1, the eggs until 6 days after fertilization stage did not hatch, but the eggs after eyed stage hatched. Hatching rate increased gradually from before eyed stage to before hatching stage. The eggs before hatching

* Technical Center, Tokyo Kyuei Co. Ltd., Shiba, Kawaguchi, Saitama 333, Japan（㧍我幸雄：株式会社 東京久栄技術センター). 
Table 1. Developmental stage and hatching rate.

Eggs were exposed to $-8^{\circ} \mathrm{C}$. Medium used was composed of $1.4 \mathrm{M} \mathrm{DMSO}, 3.2 \mathrm{mM} \mathrm{KCl}$, $2.3 \mathrm{mM} \mathrm{CaCl}_{2} \cdot 2 \mathrm{H}_{2} \mathrm{O}$ and $171 \mathrm{mM} \mathrm{NaCl}$

\begin{tabular}{lc}
\hline \multicolumn{1}{c}{ Developmental stage } & Hatching rate $(\%)$ \\
\hline Just after fertilization $(0)$ & 0 \\
6 days after fertilization $(82)$ & 0 \\
Before eyed stage (171) & 5 \\
Eyed stage (207) & 30 \\
Before hatching (289) & 50 \\
\hline
\end{tabular}

( ): total effective temperature $\left({ }^{\circ} \mathrm{C}\right.$ ).

stage showed maximum hatching rate.

It was reported that eyed eggs of salmonid fish had high tolerance against physical stimulus. ${ }^{13-16)}$ The same phenomenon was observed in this experiment, namely, the eyed eggs showed higher tolerance in the subzero temperature exposure. From above results, eyed eggs (total effective temperature: about $300^{\circ} \mathrm{C}$ ) were used in the following experiments.

\section{Effect of DMSO Concentration}

Although DMSO has been known to be a useful cryoprotectant in cryopreservation of mammalian embryos and fish sperm, there is only one report concerning the cryopreservation of fertilized fish eggs (Atlantic herring). ${ }^{11)}$ Therefore, DMSO was examined whether it is useful to cryopreservation of fertilized eggs of rainbow trout.

As shown in Fig. 1 , in $-7^{\circ} \mathrm{C}$ exposure any of the eggs tested never hatched without DMSO addi-

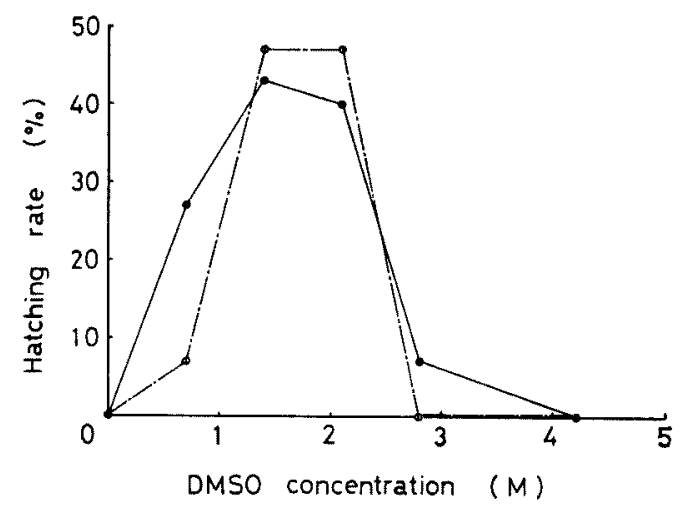

Fig. 1. Effect of DMSO concentration on hatching rate. Eggs were exposed to $-7^{\circ} \mathrm{C}$ with two media prepared as mentioned below. DMSO was added to the mineral salts solution consists of $3.2 \mathrm{mM} \mathrm{KCl}, 2.3 \mathrm{mM} \mathrm{CaCl} \cdot 2 \mathrm{H}_{2} \mathrm{O}$ and $\mathrm{NaCl}$. -— : $154 \mathrm{~mm} \mathrm{NaCl}$. (D-—(D: $188 \mathrm{~mm} \mathrm{NaCl}$.

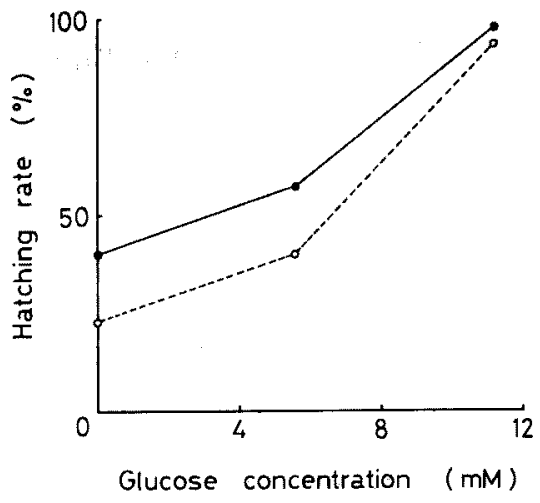

Fig. 2. Effect of glucose addition on hatching rate. Eggs were exposed to $-7^{\circ} \mathrm{C}$ with two media prepared as mentioned below. Glucose and $2.1 \mathrm{M}$ DMSO were added to the mineral salts solution consists of $3.2 \mathrm{mM} \mathrm{KCl}, 2.3 \mathrm{mM} \mathrm{CaCl}_{2}$. $2 \mathrm{H}_{2} \mathrm{O}$ and NaCl. $-: 154 \mathrm{~mm} \mathrm{NaCl}$. $\mathrm{-}-\mathrm{O}$ : $171 \mathrm{~mm} \mathrm{NaCl}$.

tion, but $\mathrm{ca} .40 \%$ of hatching rate was obtained by $1.4 \sim 2.1 \mathrm{M}$ of DMSO addition. Remarkable difference in the hatching rate was not recognized between 154 and $188 \mathrm{~mm}$ of $\mathrm{NaCl}$ concentration. In $-10^{\circ} \mathrm{C}$ exposure, hatching did not occure in spite of $0.7 \sim 4.2 \mathrm{M}$ of DMSO addition.

These results indicate that the addition of $1.4 \sim$ $2.1 \mathrm{M}$ of DMSO at $-7^{\circ} \mathrm{C}$ is one of the useful cryoprotectants for the cryopreservation of fertilized eggs of rainbow trout.

\section{Effect of Glucose Addition}

By using a medium containing DMSO and mineral salts, maximum of $47 \%$ of hatching rate was obtained (Fig. 1). Therefore, additional effect of glucose to the medium containing DMSO and mineral salts was examined in order to increase hatching rate.

As shown in Fig. 2, $11.1 \mathrm{~mm}$ of glucose addition raised hatching rate to $\mathrm{ca} .95 \%$ in $-7^{\circ} \mathrm{C}$ exposure. In $-10^{\circ} \mathrm{C}$ exposure, hatching did not occure in spite of 5.6 or $11.1 \mathrm{~mm}$ of glucose addition.

These results indicate that the addition of glucose to the medium is advantageous over the medium without glucose for cryopreservation of eggs of rainbow trout.

\section{Effect of Calf Serum Addition}

As shown in Fig. 3, the addition of $10 \sim 20 \%$ of calf serum to the medium containing DMSO and mineral salts in $-7^{\circ} \mathrm{C}$ exposure showed same 


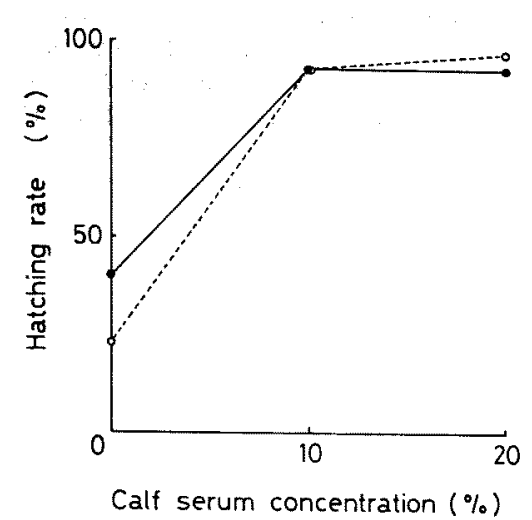

Fig. 3. Effect of calf serum addition on hatching rate. Eggs were exposed to $-7^{\circ} \mathrm{C}$ with two media prepared as mentioned below. Calf serum and $2.1 \mathrm{M}$ DMSO were added to the mineral salts solution consists of $3.2 \mathrm{mM} \mathrm{KCl}$, $2.3 \mathrm{mM} \mathrm{CaCl} \cdot 2 \mathrm{H}_{2} \mathrm{O}$ and $\mathrm{NaCl}$. - 154 mм NaCl. O---O: $171 \mathrm{~mm} \mathrm{NaCl}$.

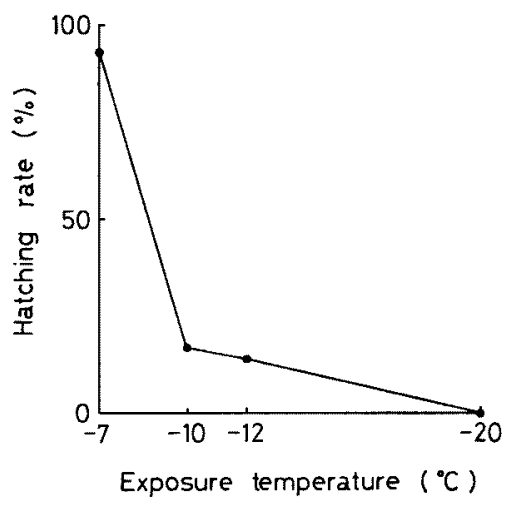

Fig. 4. Effect of subzero temperature exposures by addition of calf serum on hatching rate.

Ten per cent of calf serum was added besides DMSO $(1.4 \mathrm{M})$ to the mineral salts solution consists of $3.2 \mathrm{mM} \mathrm{KCl}, 2.3 \mathrm{mM} \mathrm{CaCl} 2 \cdot 2 \mathrm{H}_{2} \mathrm{O}$ and $171 \mathrm{~mm} \mathrm{NaCl}$.

effect (hatching rate of $\mathrm{ca} .95 \%$ ) as in the addition of $11.1 \mathrm{~mm}$ of glucose. Moreover, temperature at which eggs survived was lowered to $-12^{\circ} \mathrm{C}$ by the addition of $10 \%$ of calf serum as shown in Fig. 4.

These results indicate that calf serum is more useful than glucose as cryoprotectant for cryopreservation of eggs of rainbow trout.

In $-12^{\circ} \mathrm{C}$ exposure, a part of hatched larvae showed abnormal physiological phenomena, i.e., stopped breath, internal hemorrhage in head and opaquely white caudal part. These abnormal larvae died $c a .3$ days after hatching. At $-7^{\circ} \mathrm{C}$ or $-10^{\circ} \mathrm{C}$ in the high concentrations of DMSO (above $2.1 \mathrm{M}$ ), many of media used were not frozen. On the other hand, in the low concentrations of DMSO or at lower temperature $\left(-12^{\circ} \mathrm{C}\right.$ or $-20^{\circ} \mathrm{C}$ ), all media used were frozen. It was reported previousely that the freezing of egg's intracellular substances was fatal to the unfertilized eggs of Chum salmon, ${ }^{172}$ and the freeintracellular water was dehydrated with DMSO, and hecne $-197^{\circ} \mathrm{C}$ exposure was not fatal to rat embryos. ${ }^{18)}$ Serum was contained in the medium of cryopreservation of mouse embryos ${ }^{1 \theta, 20)}$ and rat embryos, ${ }^{18)}$ but there was no description about the effect of the serum on cryopreservation.

From the results of this study, high concentration of DMSO showed a hindrance to hatching as shown in Fig. 1 and the necessity of adding calf serum was demonstrated as additional cryoprotectant for subzero temperature exposure.

\section{Acknowledgements}

The author expresses his gratitudes to Dr. K. Kodama, Central Research Institute of Electric Power Industry (CRIEPI), for constant guidance in the course of the work, and to Mr. H. HoNDA, CRIEPI, for valuable advice.

\section{References}

1) J. H. S. BlaXter: Nature, 172, 1189-1190 (1953).

2) T. TERAO: Uo to Ran. 11, 4-6 (1960).

3) B. Truscott, D. R. Idler, R. J. Hoyle, and H. C. Freeman: J. Fish. Res. Bd. Canada, 25, 363372 (1968).

4) R. J. HoYle and D. R. IDleR: J. Fish. Res. Bd. Canada, 25, 1295-1297 (1968).

5) M. S. Mounib, P. C. Hwang, and D. R. Idler: J. Fish. Res, Bd. Canada, 25, 2623-2632 (1968).

6) B. Truscott and D. R. IdLER: J. Fish. Res. Bd. Canada, 26, 3254-3258 (1969).

7) J. R. Graybill and H. F. Horton: J. Fish. Res. Bd. Canada, 26, 1400-1404 (1969).

8) A. G. OTt and H. F. HoRton: J. Fish. Res. Bd. Canada, 28, 745-748 (1971).

9) H. Kurokura: Iden (Heredity), 33, 17-22 (1979).

10) H. Kurokura and R. Hirano: Bull. Japan. Soc. Sci. Fish., 46, 1493-1495 (1980).

11) D. G. Whittingham and H. Rosenthal: Arch. FishWiss., 29, 75-79 (1978).

12) M. Tanizaki, F. Tashiro, and M. KobayashI: in "Yogyogaku-kakuron" (ed. by N. KAWAMOTO), 
Koseisha Koseikaku, Tokyo, 1967, pp. 320-417.

13) M. Nakano and M. KawazIRI: J. Imp. Fish. Inst., 20, 81-85 (1924).

14) K. Hata: J. Imp. Fish. Inst, 23, 105-109 (1927).

15) K. Hata: J. Imp. Fish. Inst., 24, 149-152 (1929).

16) А. И. Смнрнов: Sake to Masu (Translated from Russian by H. Sakiura), 3, 41-44 (1961).
17) A. Sakal: Low Tem. Sci., 6, 147-157 (1951).

18) K. Utumi, E. Okimasu, and M. Yuhara: Sci. Rep. Fac. Agr. Okayama Univ., 47, 59-66 (1976).

19) D. G. Whittingham: Nature, 233, 125-126 (1971).

20) D. G. Whittingham, S. P. Leibo, and P. MazUR: Science, 178, 411-414 (1972). 